\title{
Joint-use Libraries: Co-operation Between Public Libraries and School Libraries in Theory and Practice
}

\author{
Lourense H. DAS, Consultant \\ Meles Meles School Library Service, Baexem, Netherlands
}

\begin{abstract}
Exploitation of school libraries by public libraries is strongly promoted by (local) politicians and decision makers. In the Netherlands this is influenced by a reform in the educational system in the 1990's and the reconsideration of public libraries in the local area. The school library has become a marketing target. Public libraries and school libraries have varying roles. These roles are not similar but complimentary. Key factors for successful co-operation are the recognition of the role of the school library in the educational process and the competencies of the school librarian. As an example of a cooperation process, the establishment of a joint-use library in the brand new public library branch in the new district Ypenburg, will be described.
\end{abstract}

\section{Introduction}

Based on the starting point that there is a considerable overlap in the roles of school and public libraries (Boom, 2003), many types of co-operation between public libraries and school libraries have been practiced over the years in almost every country in the world. The joint-use library can be seen as the most ultimate type of co-operation. A joint-use library can be defined as "a library in which two or more distinct groups of users have equally priority in the same premises and which is jointly owned, funded and managed by cooperative agreement between two or more separate authorities" (Queensland, 1996). A joint-use library is not the only term used for this type of library. Other terms are: combined library, dual-use library or partnership library. libraries:

In general, it is possible to describe four different types of these joint-use

- A school library or school media resource centre in a school also used by the community

- A joint-use library on the school premises

- A joint-use library on the premises of the public library

- A joint-use library in a separate building

And of course there are many variations to these types, dependent upon the national, regional or even local situation.

In historical perspective the joint-use library is not a new phenomenon. Examples are known from the 19th century until now in countries like the USA (Fitzgibbon, 2000), Australia (Bundy, 1998; Bundy, 2001), Sweden and the UK (McNicoll, 2003).

For this paper we focus on co-operation and joint-use libraries in the Netherlands. The joint-use library here is limited to libraries where a primary or secondary school and public library share one facility. In the Netherlands primary education is for children from 4-12 years; secondary education is for children from $12-18$ years. In the Dutch language the most used expression for joint-use library is 'Brede School'. The term Brede School is mainly used for a joint-use facility for one or more primary or secondary schools, who share a library with the public library, and in most cases other partners like 
a child care institute, local museum, theatre and a community centre.

Over the past few years, collaboration between public libraries and school libraries has become extremely popular in the Netherlands. In articles, workshops and during meetings, representatives from public libraries (national, regional and local) express the opinion that collaboration is good for the public library. According to these representatives the public library should exploit school libraries. The school library has become a marketing target. In this respect it is interesting to notice that a statement from the OECD underlines this: "No school library designed for the information society will operate as a stand alone, independent, self-sufficient entity”...”As the school library is transformed from a service, confined to the needs of a particular school to a service which is part of a network and open to everyone in the community, a very different set of resource arrangements needs to apply" (OECD, 2001)

Despite this interest from the public libraries in school libraries, no research has been carried out into the effectiveness of co-operation and joint-use libraries. Decision makers (politicians, school administrators and librarians who do not work in school libraries) promote partnerships as being the most economical way to establish the facility for both the community and the school. The question as to whether or not these partnerships are effective for the schools and education in general, has never been investigated. Public libraries are trying to take a leading role in the development of school libraries. What is most interesting is the way in which administrators accept the fact that school librarians play a subordinate role. Because there is no Dutch research available, I am using references from other countries and will try to find out how they apply for the Dutch situation.

\section{Levels of co-operation}

In references on co-operation between schools and public libraries many pros and cons can be found. In most cases successful cooperation depends on the national, regional or local situation:

- How are public and school libraries organised,

- Are public libraries wide spread all over the country,

- Are there many community libraries and school libraries,

- Are there any rules and regulations with regard to (co-operation between) public libraries and school libraries

Besides the ultimate level of co-operation, the joint-use library, other levels are practised as well such as:

- Networks and resource sharing - sharing knowledge and expertise

- Cooperation in building collections - sharing collections

- Cooperation in providing information services and instruction - public library visits, joint activities

- Cooperation to encourage reading and literacy - author-visits, book promotion projects

- Joint memberships

- Joint personnel

All of these types can be found in the Netherlands. Many public libraries work closely together with school libraries: they provide schools with collections, organise joint activities like author visits and share databases. The city libraries of Rotterdam and 
Eindhoven supply professional librarians on a secondment basis for schools in their region. And joint-use libraries can be found in the city's: Meerssen, Breukelen, Leek and Purmerend.

\section{The varying roles of school and public libraries}

In most of the studied literature the varying role of the school and public library is described. The fact the school library is a library, with a specific group of users, a specific collection, a specific cataloguing system and a specific approach and methods, leads to the conclusion that the school library can be described as a special library. On the other hand, public libraries are more and more reconsidering their core business. Lifelong-learning and the need for educational activities in the community thrives public libraries and school libraries together. A cursory glance may indicate that the borderline between the two different kinds of libraries is becoming blurred. An interesting question in this respect is therefore: does the school library still have a unique and specific role that cannot be executed by the public library?

The most obvious difference between a school library and a public library is the role that the school library plays in the primary educational process. In the primary educational process the school librarian and the teachers work closely together: "It has been demonstrated that, when librarians and teachers work together, students achieve higher levels of literacy, reading, learning, problem-solving and information and communication technology skills” ..."The school library offers learning services, books and resources that enable all members of the school community to become critical thinkers and effective users of information in all formats and media"... "The materials complement and enrich textbooks, teaching materials and methodologies.” (IFLA, 1999). Own working experience for the past 25 years and personal communication with many school librarians indicates that the school library is inextricably bound up with the educational process and has (depending on the specific school) a specific group of users, in a specific age-group, with often, a special cultural and social background.

The public library key missions relate to information, literacy, education and culture in a more general sense (IFLA, 2002). The wide range of users in the public library who differ widely in age, cultural and social background and education expresses this. However, the role of the public library is changing: according to the life-longlearning principles, people nowadays are expected to educate themselves continuously. Education starts after birth and doesn't stop after secondary school. It continues until the end of a person's life. The public library is an important contributor to education - not only during primary and secondary school, but also in a much broader sense, from babies and pre-schoolers to senior citizens. The public library helps people of all ages to pursue personal interests and contributes to education as a basis for 'home-schooling', especially in rural areas when there is no school nearby and in cases children cannot go to school, due to illness or other circumstances. It also provides activities and opportunities during school holidays.

\section{Unique and complimentary}

The role of the school library is unique in the way the school library is part of the primary educational process and the role the school librarian plays in this educational process. The school librarian is not just a librarian, but also an information specialist, a teacher, an instructional assistant, in the Netherlands often described as 'a coach'. The 
students are provided instruction integrated into the curriculum, and in the skills needed to identify an information need, to find, to evaluate and organize information and in effective information use. These unique competencies of the school library staff are different from those of the public library staff. They are clearly described as "the school library mission is to teach, not to do for people" (Flagg, 1999). Furthermore there are other aspects that emphasize the unique role of the school library, aspects like security, censorship and filtering. And the school library is free of charge for all members of the school community.

The role of the public library can be described as complementary; it is used 'voluntarily' at the user's own time and convenience when they want to use it. Visiting the public library can also be described as a leisure activity: people use the public library to relax and to pursue a hobby. The public library offers free admission but in the Netherlands often not free of charge.

Considering the above I have come to the conclusion that a school library is not 'a library in a school, but education in a library'. School attendance is compulsory and is part of students' daily activities. It is impossible to detach the school library from the educational process. Public libraries and school libraries are complementary: school libraries take their place in the primary educational process and public libraries complement this role by providing total services for recreation, personal interests and personal information for the modern, sophisticated digitally-focused child and adolescent. Very important is the role of the public library as a service organisation. This means that the public library can service the school library in many ways and complement the needs that the school library is unable to fulfil.

\section{Opportunities, pitfalls and threats}

Surveys and research done in e.g. Australia and the UK give a lot of information on the opportunities, pitfalls and threats to make co-operation and joint-use libraries successful. Below you will find a concise overview, drawn from several resources (Bundy, 1998, 2001), (Fitzgibbons, 2000), (Miller, 2001), (McNicoll, 2003), (Queensland, 1996), (Division, 1998) complemented with a list of success-factors.

\section{Opportunities:}

- Access to a greater quantity of resources, information and knowledge

- School librarian, mostly an on-person job, will have colleagues to work and discuss with

- Extended hours for students, including during school holidays

- Efficient use of public money

- Contribution to the community

- Fits seamlessly in the life-long-learning process

- Meeting place for the community with a window to the school

Pitfalls:

- Different missions and starting points: needs a lot of consultation = time + money

- Different collection profiles

- Public library membership fees for use of materials and facilities

- Public librarians inadequately trained for dual role

- Different standards and guidelines - different regulations and law

- Geographical distances between the two organisations 


\section{Threats}

- Insufficient commitment from both sides - cooperation can only succeed when both partners have a strong contribution on equal basis. One cannot substitute for the other

- Economic reasons as a starting point - partnerships have a price tag! "There are few, if any, savings in recurrent operational costs to be made by instituting a jointuse library" (Guidelines, 1996).

- Organisational differences: the school library is part of the school-organisation; depending on the national or local situation, the public library is an independent organisation. There are differences in financing, operating procedures, responsibilities, and culture.

- Absence of an independent consultant who can coordinate the process (Fitzgibbon, 2000). This person will be able to make sure a party will not be overlooked, that there is common mission and a mutual contribution and that the people who have to carry out the work have a strong commitment and feel happy with the new situation. They should not have the feeling that one of the parties is overruling.

\section{Success-factors}

Plan the cooperation carefully

- Look carefully at similarities and differences in mission statements, users, collection, approach and define them

- Look for complementary roles - not duplication

- Make sure there is a surplus value for both parties

- Commitment and involvement of all partners, including staff carrying out the work

- Define responsibilities and record them

- Design an evaluation program

Administration and funding

- Prepare an agreement

- Define budgets

Information, resources and facilities (depends on level of cooperation)

- Agree on the policy

- Define standards that fit both libraries

- Define the activities, user groups etc.

- Focus on the improvement of the services, facilities etc., not on saving money

- Make sure all user-groups feel comfortable with the (new) situation

- Negotiate for the best solution and opportunities

- Provide training for librarians in special (educational) skills

\section{Introduction}

\section{Co-operation in the Netherlands}

The history of school libraries in the Netherlands is rather short. The first secondary school libraries with a professional library with qualified staffing and substantial collections were established in the 1970's. In that same period collaborative 
projects between public libraries and school libraries were initiated, including a few jointuse libraries. In the eighties, these joint-use libraries were abolished, due to a new revival of school libraries. The situation in the nineties was the opposite: new co-operative projects started locally, including joint-use libraries. During the past few years, the interest in collaboration has grown for the following reasons:

- Economic reasons and cost reduction. Schools and public libraries are forced to work more efficiently. In the opinion of decision makers (politicians and administrators) there are economical reasons for collaboration (school libraries are thought of as a marketing object)

- 'Digitalisation' of information and possibilities of connecting informationnetworks: public libraries are offering on-line databases that cannot be purchased by individual schools

- The department of Culture merged into the Ministry of Education, Culture and Science. Policy-officers from the department of Culture (public libraries) suggested co-operation between school libraries and public libraries for economic reasons

- The national administration was no longer involved with education and public libraries; these responsibilities went to the local authorities, forcing them to set up alliances. Schools became responsible for their own policies and their own work and alliances have therefore become essential for improvement and reforms of education and services.

Changes in the Dutch school system since the eighties have been made in response to the perceived problems for students who are not being able to successfully continue tertiary education at universities and higher vocational courses, because they lacked the necessary skills in independent learning and research. Consultation between the Ministry of Education and the universities led to a decision to update the education system in secondary schools, particularly given the emergence of information technology and it's new place in the curriculum (Das, 2001).

\section{Educational system in the Netherlands}

As a result, a completely new programme of study was introduced: The 'Basisvorming' was introduced in 1991. The 'Tweede Fase' was introduced in 1996, and finally reforms in the VMBO followed in 2001. Now the setting for Dutch education includes primary education (4-12 years of age), followed by three types of secondary schools:

- Junior general and pre vocational secondary education (VMBO) - four years

- Senior general secondary education HAVO ( Hoger Algemeen Voorbereidend Onderwijs) - five years

- Pre university education VWO (Voorbereidend Wetenschappelijk Onderwijs) six years

"What is interesting in this new framework are the comprehensive options available to students, and the gradual transition to independent learning, integrated into the final stages of secondary education. In both HAVO and VWO, the last two to three years of the education framework sees students working the so-called 'Second Phase' (= Tweede Fase). In this period students are expected to study independently, whilst the teachers take on the role of learning coaches. Students no longer attend regular class lessons, these having been changed to lectures, with several hours per week being 
reserved for self-tuition. Also in the course of the VMBO students are generally working more and more independently, at their own paces and learning level” (Weeber, 1994).

This is the official text of the brochure of the Ministry of Education. But since the changes were introduced from 1993, still a lot of schools are having problems to let their pupils study independently.

\section{Consequences for schools and school libraries}

The three new educational systems required a lot of changes in the curriculum and led to a great deal of discussion within the schools. While the government remains convinced of the advantages of the new system, teachers have not always been as comfortable with the changes for a variety of reasons. They have criticized the government for providing insufficient funds to implement the new systems successfully, given the need to invest in new materials, curriculum methods and facilities.

Part of the new system was (and this was mentioned for the first time) the implementation of school media resource centres, in Dutch called 'schoolmediatheken'. The slogan was that the school library is 'the heart of the Studiehuis', (PMVO, 1996). Despite the slogan, no standards or guidelines for school libraries were drawn. And no extra funding was made available.

The new educational system was followed by more revolutionary changes for schools:

- A new administrative system was introduced

- A new staffing system was introduced

Schools tried to anticipate to the educational changes by employing more non-teaching staff and they started to set up school libraries. This became possible because of the new administrative system. This system included more freedom for schools to spend their budget as they please and together with the assessment of schools by the school inspection board, it became vital to reconsider priorities and to make investments. The new staffing system forced schools to think about the position and payment of the school librarian. The Government stimulated the implementation of personal computers and other facilities in the schools. Changes in the behaviour of the modern independent pupil meant that, in many cases he chooses his own school. And as pupils tend to choose a school with a lot of modern technology and facilities, school libraries were given a boost. Interesting however in this respect is, that schools invest in facilities (computers) and buildings, but not in professional staff for the school library. Presently, most secondary schools have established a facility that can be described as a school library, although these libraries differ from school to school. Some schools have only a 'computer-room' with a caretaker in charge; others have well-equipped libraries with a wide range of materials and a chartered librarian assisted by administrative assistants. As a result, the way the school library is implemented in the curriculum also differs from school to school.

Co-operation: $1+1=3$

Public libraries are in the middle of a process of reform. Together with transfer of financial responsibilities from the national administration to local authorities, a new structure for public libraries in the Netherlands was introduced and is presently being executed. Part of this new structure requires that public libraries should proactively find new goals to fulfil the needs of the public and new markets to strengthen their position (Veen, 2005). Local authorities that are responsible for education in their 
own area stimulate partnerships between public libraries, schools and others. In many cases economical aspects are the starting point for these alliances. Politicians and public library managers emphasize the role of public libraries in information literacy. It has become clear, however that school librarians and public library librarians have a difference of opinion regarding the definition of information literacy and the way information literacy skills should be taught (Norma Verheijen, 2005). The divergent view on this subject makes it difficult to play a joint role and take responsibility for the improvement and reforms of education and services. This is especially true in the perspective of the particular role of information literacy in the so-called knowledge society.

Local initiatives in the Netherlands have shown that co-operation is an interesting option, for developing high-quality school libraries and media centres. However this all depends on the local situation and the readiness to recognize the specific roles of both the public library and the school library. The offered services and facilities by public libraries differ from city to city. In general, children can use the public library free of charge, but some public libraries have (reduced) fees for children above 14 years old. The same policy applies for the use of computer-facilities. Fees are used from Euro 1,00 for 30 minutes up to Euro 2,50 for one hour. Use of the school library is free of charge including free use of the Internet and collection materials. Guidance and security is another aspect that public libraries cannot always supply. There is not enough personnel available and filtering internet-access is not part of the public library policy. Collections differ from collections in school libraries. Particularly in small cities and villages the collection doesn't fulfil the needs of pupils in secondary schools, especially with regard to literature in foreign languages.

The differences in local policies, funding and performance of public libraries make an emphasis on a nation-wide strategy on collaboration difficult to expedite. A joint agreement about the necessity of effective school libraries is the foundation for successful co-operation. In the end, the outcome of collaboration should be additional value for both partners: 'the whole should exceeds the sum of it's parts' to make the investment in cooperation worth while. As it is put in a well-known commercial in the Netherlands, $1+1$ $=3$.

\section{School librarians: followers or leaders?}

Another aspect that hasn't been mentioned is the position of the school librarian or school library media specialist. An important factor is that the educational role of the school library is not nationally recognized. There is no national law, stating that every school should have a school library and/or a school librarian. The school library is often not an object of assessment by the national inspection board, because there are no national accepted criteria, guidelines or standards for this assessment. Schools are not stimulated to employ a chartered school librarian. There are no training courses for school librarians available at an adequate level. School librarians are very often seen as supporting staff without educational responsibilities. It is sad to note that in several cooperation projects, the school librarian has been completely forgotten. Lack of professional staffing in the school library combined with the unwillingness of school administrators to employ chartered librarians has put the Dutch school libraries and librarians in a vulnerable position. In 2004, the Dutch School Library Association (LWSVO, 2004) developed a professional profile for school librarians in secondary 
schools. Unfortunately this paper has not a national legal weight. School managers cannot be forced to follow these guidelines.

Because of the absence of professional school librarians who are able to defend the mission and objectives of the school library and its role in the educational process, and the economical aspects mentioned above, public libraries take the initiative to exploit the situation and recommend joint-use libraries. Without the expertise of the school librarian, the position of the schools towards the pro-active attitude of the public library is very weak and administrators and headmasters are easy targets. It is interesting to note that professional school librarians, who used to work in a public library, are especially critical towards the policy of the public libraries and often ask 'what do the public libraries want from us?'

Meanwhile, a lot of school librarians, professionals and assistants are worried about their position: will they be overruled by the public library? This calls for a new attitude and a new revival: the school librarian as the leading partner in the co-operation process, the school librarian as the 'liaison officer' between education (pupils and teachers) and the public library. To become a leader it is vital to have the necessary competencies: professional training as school librarian or teacher-librarian, knowledge and skills, recognition as a professional in education and information world, professional attitude, passion and commitment. In the years to come, these competencies will be the success factors in co-operation and also joint-use libraries, if proven to be desirable.

\section{Conclusions}

Research from other countries shows that successful joint-use libraries are often situated in rural areas where it is impossible to establish separate public libraries and school libraries are already being used in a more or less professional way. In the Netherlands, public libraries are spread throughout the country and are complemented by mobile services. Although they are also suffering from budget cut, in general they have a better outlook than school libraries, with regard to funding as in buildings (locations), and personnel. The Netherlands is a very densely populated country. The rural areas that have managed to survive urbanisation cover only a small area and, in most cases are located close to a larger city.

Schools that employ a professional school librarian are not particularly interested in co-operation with public libraries. They are willing to co-operate as long as the services provided by the public library fit within the mission of the school and its educational objectives. Co-operation with the public library should also not be too time consuming. The question whether or not co-operation and joint-use libraries are essential to effective school libraries depends upon the local situation. The complimentary roles of the public and school library should be emphasized and exploited, and partnerships based on equality, appreciation and the key position of both partners in the knowledge society, should be built. Collaboration based merely on economic profit and/or for strategic or opportunistic reasons is doomed to fail. In order for successful partnerships to take place, it is absolutely vital that both partners are committed and have a strong positive attitude towards the partnership. They should also make an invest of resources, money, personnel and time into the partnership.

The following recommendations should apply for the Dutch situation:

- For schools, a joint-use library in the school is the best option. The students can stay in a secure environment, where all kinds of teaching opportunities are available. If co-operation is to be worthwhile for both partners, then public 
libraries should advocate the importance of school libraries managed by professional school librarians or teacher-librarians.

- Research the necessity of a partnership or joint-use library

- Make sure all partners contribute equally, at the same level and that one partner does not overrule the other

- Find staff that is enthusiastic about the collaboration, and passionately wants to make co-operation work

- Make sure the school has a professional school librarian at its disposal

- Determine the level of co-operation and set a time schedule

- Organize suitable refresher courses for staff of both the school and the public library

- Find enough budget to fulfil all the needs of the partnership, not only at the beginning of the project, but also for the years that follow

- Have signed agreements and clear division of responsibilities

- Have an independent consultant guide the process

- Develop an evaluation plan

As an example of a new partnership in the city of The Hague, the project called 'The Hague Spring' will be described.

\section{The Hague Spring: joint-use library in progress}

The city library in The Hague and the Esloo Educational Board have decided to co-operate in order to fulfil literature and information needs of the pupils. The Esloo Educational Board comprises of six schools for pupils from $12-18$ years old. Three of the schools are involved in the co-operation project: the Overbosch College and St. Paul's are both schools for pupils from $12-16$ working in the stream VMBO; the third school is the Montaigne Lyceum, a large school with junior general and pre vocational secondary education (VMBO), senior general secondary education HAVO and pre university education VWO. The Montaigne lyceum, now situated in the village Nootdorp, near The Hague, will move to a recently built new district, called Ypenburg. In this district, there are plans for a new school and a brand new public library. The new library covers an area of 850 square meters and has an expected membership of 6000 people, 250.000 loans and 100.000 visitors per annum. The new school will be built in the vicinity (approx. $1 \mathrm{~km}$ from) the library and presents itself as a co-operative organisation. Education will collaborate and interact with a number of relevant organizations (corporate and noncorporate) in the new district. The vision of the school can be described as: 'learn from yourself, learn with each other and learn in the world'. The expected number of pupils in the new location is 1200. This paper will focus on the collaboration between the Montaigne Lyceum and the new public library in the district that is now under construction, Ypenburg. This new joint-use library is expected to open in April 2006.

\section{Project description}

Main objective: in order to promote their educational and development process, pupils should have optimal access to knowledge and information, and learn skills in acquiring, evaluation and processing that information and knowledge. 
Sub objective: Pedagogical and didactical: Pupils have to become information literate. Teachers and librarians must have the competencies to teach pupils how to become information literate.

Organizational: in their individual way, both the school and the public library have to organize prompt and unobstructed access to the imperative information and knowledge.

\section{Results}

To realize these objectives, it is necessary to describe the stocktaking process and the development of the different aspects of the project. These aspects can be divided in pedagogical/didactical and organizational aspects, followed by tangible final products. The pedagogical and didactical aspects are:

- Relevant information literacy (IL) skills for teachers and pupils have to be described. The IL skills will be integrated in the curriculum and assessment of these skills will take place within the educational projects.

- Competencies of both teachers, educational assistants and library staff need to be established, followed by a description of imperative courses to achieve these competencies. Assessment will take place in educational projects in which teachers, librarians and educational assistants will work closely together. Both competencies and courses should be effective for the complementary co-operation between teachers and library staff in teaching and coaching pupils in the information literacy process.

- Collection profiling based on the educational goals for education and pupils. The organizational aspects are:

- A (digital) up-to-date collection of materials will be provided, based on quality criteria, the curriculum and needs of the school and its educational profile. Assessment takes place in both the public library and the school.

- The location and availability of materials are recorded, so that optimal cooperation between the public library in the city of The Hague, the new district library and the school can be established.

- Mapping the facilities and staffing for the school and the district library. Assessment takes place in both the school and the library. Formulation of a detailed operational list of demands.

- Formulation of the legal, organizational, physical and financial consequences of the co-operation in order to establish an optimal co-operation for the partners. Assessment takes place based on good-practices in the Netherlands. The tangible final products are:

- A scenario for cooperation between schools and libraries in general, based on query-based education.

- This scenario has to be applicable to co-operation between other schools managed by the Esloo School Board and other schools in the region and the libraries in The Hague region

- Structural organizational and substantial co-operation between the Montaigne Lyceum and the district library in Ypenburg.

- Skills for pupils, librarians and teachers. 
At this moment (April 2005) the project is in the middle of this process. A few interesting aspects, at this point are:

- An estimate of 2500 hours work has been made for all participants for the development of the project

- The school does not have a qualified school librarian

- According to the plan, the joint-use library will be located in the public library, situated approx. $1 \mathrm{~km}$ from the school

- Assessment takes place based on good practices in the Netherlands; up until now, it would seem that, so far, good-practices have not been not recorded

- The public library is responsible for building up the collection, but the librarian who is in charge has no prior experience in making a collection for a school library

- As yet, questions concerning the type of indexing which should be used have not been answered

- Required competencies for the library staff have not been determined

- As yet, questions with regard to refresher courses for the public library staff have not been answered

\section{References}

Boom, D., Lekanne Deprez, F.R.E. \& Tissen, R.J. (2003). Van rups tot vlinder: een bladwijzer voor de toekomst van bibliotheken in Nederland. Alphen aan den Rijn: Kluwer.

Bundy, Alan (2001). Essential connections: school and public libraries for lifelong learning. APLIS, 14, (4), 142-158

Bundy, Alan (1998). Widening client horizons: joint-use libraries in the 1990s. APLIS, 11, (1), 4-16

Das, Lourense (2002). Library partnerships in the Netherlands. School Libraries World Wide, 8, (2), 82-93

Division for libraries and community learning (1998). Combined school and public libraries: guidelines for decision making, $2^{\text {nd }}$ ed. Madison, Wisconsin: Wisconsin Department of Public instruction.

Fitzgibbons, Shirley A. (2000). School and public library relationships: essential ingredients in implementing educational reforms and improving student learning. School library Media Research, 3, 1-54

Flagg, Gordon (1999). Share and share alike? American Libraries, 30, (2) 40-42. 
IFLA (1999). IFLA/UNESCO School library Manifesto: The School Library in Teaching and Learning for All. Retrieved from http://www.ifla.org/VII/s11/pubs/schoolmanif.htm

IFLA (2002). IFLA/UNESCO Public Library Guidelines for development. Retrieved from http://www.ifla.org/VII/s8/proj/mts.htm

LWSVO (2004). Beroepsprofiel Schoolmediathecaris Voortgezet Onderwijs. Retrieved from http://www.lwsvo.nl

McNicoll, Sarah (2003). Joint use libraries in the UK. APLIS, 16, (2), 81-90.

Miller, William \& Pellen, Rita M. [ed] (2001).- Joint-use libraries. New York [etc.]: Haworth Information Press.

Norma Verheijen: interview (2005). Dossier Kennis \& Media, 4, (2), 46-47

OECD (2001). School libraries and resource centers. Paris: OECD.

PMVO (1996). De bibliotheek in het Studiehuis / Den Haag: Stuurgroep Profiel Tweede Fase Voortgezet Onderwijs.

Queensland Government, Department of Education (1996). Guidelines for the development of Joint-use School-community libraries. Queensland: Queensland Government, Department of Education.

Veen, Hans (2005). Openbare bibliotheken: branche in beweging, overheden in verwarring. Informatie Professional, 9, (4), 14-21

Weeber, Frans, \& Ahlers, Jos; transl. by Janey Tucker (1994). Going to school in the Netherlands. Den Haag: LDC.

\section{Author Note}

Lourense H. Das graduated in library sciences (BA) in 1976. Since then, she has worked in various school or educational libraries. In 1998, she founded Meles Meles School library Service, a private organisation for school libraries and school librarians. Meles Meles advises, guides, and coaches schools and school librarians in the field of school librarianship. Lourense has been a part-time policy officer for the Dutch Organisation for School librarians in Secondary Schools (LWSVO) since October 2000, co-ordinator of ENSIL (European Network for School Libraries and Information Literacy) since March 2003 and Director Europe for IASL since July 2003. 
Reproduced with permission of the copyright owner. Further reproduction prohibited without permission. 